Anais da Academia Brasileira de Ciências (2006) 78(3): 463-474

(Annals of the Brazilian Academy of Sciences)

ISSN 0001-3765

www.scielo.br/aabc

\title{
Crystal habits and magnetic microstructures of magnetosomes in coccoid magnetotactic bacteria
}

\author{
ULYSSES LINS ${ }^{1}$, MARTHA R. McCARTNEY ${ }^{2}$, MARCOS FARINA ${ }^{3}$, \\ RICHARD B. FRANKEL ${ }^{4}$ and PETER R. BUSECK ${ }^{5}$ \\ ${ }^{1}$ Instituto de Microbiologia Professor Paulo de Góes, CCS, Universidade Federal do Rio de Janeiro \\ Cidade Universitária, 21941-590, Rio de Janeiro, RJ, Brasil \\ ${ }^{2}$ Center for Solid State Science, Arizona State University, Tempe, Arizona, 85287 USA \\ ${ }^{3}$ Instituto de Ciências Biomédicas, CCS, Universidade Federal do Rio de Janeiro \\ Cidade Universitária, 21941-590 Rio de Janeiro, RJ, Brasil \\ ${ }^{4}$ Department of Physics, California Polytechnic State University \\ San Luis Obispo, California, 93407, USA \\ ${ }^{5}$ Departments of Geology and Chemistry/Biochemistry, Arizona State University \\ Box 871404, Tempe, Arizona, 85287-1404, USA \\ Manuscript received on September 9, 2005; accepted for publication on February 17, 2006; \\ contributed by RICHARD B. FRANKEL*
}

\begin{abstract}
We report on the application of off-axis electron holography and high-resolution TEM to study the crystal habits of magnetosomes and magnetic microstructure in two coccoid morphotypes of magnetotactic bacteria collected from a brackish lagoon at Itaipu, Brazil. Itaipu-1, the larger coccoid organism, contains two separated chains of unusually large magnetosomes; the magnetosome crystals have roughly square projections, lengths up to $250 \mathrm{~nm}$ and are slightly elongated along [111] (width/length ratio of about 0.9). Itaipu-3 magnetosome crystals have lengths up to $120 \mathrm{~nm}$, greater elongation along [111] (width/length $\sim 0.6$ ), and prominent corner facets. The results show that Itaipu-1 and Itaipu-3 magnetosome crystal habits are related, differing only in the relative sizes of their crystal facets. In both cases, the crystals are aligned with their [111] elongation axes parallel to the chain direction. In Itaipu-1, but not Itaipu-3, crystallographic positioning perpendicular to [111] of successive crystals in the magnetosome chain appears to be under biological control. Whereas the large magnetosomes in Itaipu-1 are metastable, single-magnetic domains, magnetosomes in Itaipu-3 are permanent, single-magnetic domains, as in most magnetotactic bacteria.
\end{abstract}

Key words: magnetite, magnetotaxis, high-resolution transmission electron microscopy.

\section{INTRODUCTION}

Magnetotactic bacteria orient and migrate along geomagnetic field lines. Each cell contains magnetosomes, which are membrane-enclosed, nanoscale, iron-mineral crystals (Bazylinski and Frankel

*Member Academia Brasileira de Ciências

Correspondence to: Ulysses Lins

E-mail: ulins@micro.ufrj.br
2000, 2004). The magnetosomes are typically arranged in one or more chains, with the chain orientation close to the axis of motility of the cell. The chain of magnetosomes constitutes a permanent magnetic dipole in each cell that causes the cell to remain oriented along the local magnetic field as the bacterium swims. This orientation presumably increases the efficiency of the cell in finding the 
preferred oxygen concentration in chemically stratified sediments or water columns (Frankel et al. 1997).

In micro-aerobic freshwater and marine environments, magnetotactic bacteria with magnetite $\left(\mathrm{Fe}_{3} \mathrm{O}_{4}\right)$ magnetosomes occur, whereas in sulfidic environments magnetotactic bacteria that produce greigite $\left(\mathrm{Fe}_{3} \mathrm{~S}_{4}\right)$ magnetosomes are present (Simmons et al. 2004). The magnetosome membrane is presumably a structural entity that anchors the mineral particles at particular locations in the cell, as well as the locus of biological control over the mineralization process (Matsunaga and Okamura 2003, Schüler 2004).

Magnetosome magnetite crystals in different bacterial species or strains have different, but consistent, projected shapes when observed by transmission electron microscopy (Bazylinski and Frankel 2000, Devouard et al. 1998). Idealized crystal habits of magnetosome magnetite crystals in a number of magnetotactic bacteria have been inferred from 2D high-resolution lattice images, assuming low-index faces (Bazylinski et al. 1994, Frankel and Buseck 2000, Mann and Frankel 1989, Mann et al. 1987, Matsuda et al. 1983, Meldrum et al. 1993a, b, Thomas-Keprta et al. 2001). In magnetotactic spirilla, the idealized crystal habits are equidimensional cuboctahedra comprising $\{100\}$ and $\{111\}$ faces (Mann et al. 1984). In a number of other magnetotactic bacteria, including cocci and vibrios, the crystals are elongated along the [111] axis parallel to the magnetosome chain direction and the projected shapes are quasi-rectangular. The idealized habits for the crystals comprise $\{100\},\{111\}$, and $\{110\}$ forms with 6, 8, and 12 faces, respectively. The elongation along [111] results in a non-equidimensional crystal habit with two groups of six $\{110\}$ faces and two groups of two and six $\{111\}$ faces. The six $\{100\}$ faces remain equidimensional. The result is a prism-like arrangement with a hexagonal crosssection perpendicular to [111] through the center of the crystal (Towe and Moench 1981). The remaining faces form corner facets at the intersections between the body $\{110\}$ and end-cap $\{111\}$ faces (see
Figure 2). The sizes of the crystals, the width/length ratios, and the relative sizes of the corner faces differ between species, resulting in the distinctive projected shapes.

It is possible to determine such complex habits in small crystals with techniques such as electron tomography, which involves carefully controlled TEM tilting experiments (Buseck et al. 2001). However, electron tomography does not give information about magnetic structure. Off-axis electron holography, on the other hand, can be used to obtain both magnetic and structural information about nanometer-sized magnetic crystals. In this paper we report on the application of electron holography and high-resolution transmission electron microscopy to compare the crystal habits and magnetic structures of magnetosomes between two types of magnetotactic bacteria collected at the same location in Brazil. The magnetosomes studied here were obtained from two coccoid morphotypes of magnetotactic bacteria in a brackish lagoon at Itai$\mathrm{pu}$, Brazil, which is located on the coast of Brazil north of Rio de Janeiro (Farina et al. 1994, Lins et al. 1994). At least four coccoid morphotypes with magnetite magnetosomes, Itaipu-1, -2, -3 and -4 (Spring et al. 1998), a rarely observed rod-shaped bacterium (Lins and Farina 1998), and multicellular magnetotactic prokaryotes (U. Lins, unpublished results), occur in the lagoon. Itaipu-1, the largest coccoid organism, contains two separated chains of magnetosomes; the magnetosome crystals have roughly square projections, lengths up to $250 \mathrm{~nm}$ and width-to-length ratios of about 0.9 (Farina et al. 1994, Spring et al. 1998). These are the largest-volume magnetosome crystals yet reported. Itaipu-2 and -4 are smaller cocci containing magnetosome crystals that are smaller, but with similar projected shapes to those in Itaipu-1. Itaipu-3 has magnetosome crystals that are elongated along [111] (width/length $\sim 0.6$ ), with lengths up to 120 $\mathrm{nm}$ and prominent corner facets. The combination of TEM microdiffraction and high-resolution imaging was used to provide information on the shapes of individual magnetosomes (Lins et al. 2005). It is re- 
markable that the crystals in Itaipu-1 are not only all aligned with [111] elongation axes parallel to each other along the chain, but are also ordered rotationally perpendicular to the chain axis, with like corner faces of adjacent crystals facing each other (Lins et al. 2005).

\section{MATERIALS AND METHODS}

\section{SAMPLE PREPARATION}

Itaipu-1 and Itaipu-3 bacteria predominated in the lagoon at the time the samples for this study were collected. Cells of Itaipu-1 and Itaipu-3 were isolated from sediment and water samples by using glass chambers with capillary ends positioned inside magnetic coils (Lins et al. 2003). Cells inside the glass chamber swam in the direction of the north magnetic pole of the coil (i.e., antiparallel to the magnetic field generated by the current in the coils), and accumulated at the end of the capillary, from where they were collected and deposited into Eppendorf plastic tubes. Whole cells, or magnetosomes extracted from disrupted cells, were deposited on holey-carbon TEM grids. A protocol modified from Towe and Moench (1981) was used for disruption of magnetotactic bacteria and isolation of crystals. Briefly, cells were concentrated at the bottom of an Eppendorf tube by centrifugation, re-suspended in a solution containing detergent (SDS, about $20 \% \mathrm{w} / \mathrm{v}$ ), and magnetically concentrated with a strong rare-earth magnet positioned at the bottom of the tube. In order to eliminate the detergent and dissolved organic material, the supernatant was discarded, the pellet was re-suspended in distilled water, and the magnetite crystals were reconcentrated at the bottom of the tube. This process was repeated until no detergent remained in the sample. The isolated magnetite crystals were further treated with a hot $\mathrm{NaOH}$ solution (circa $60^{\circ} \mathrm{C}$ ) and washed in distilled water, as described above. Water drops containing the crystals were spread over the grids. Grids were then air-dried and observed under the transmission electron microscope. In some cases the crystal suspension was sonicated prior to deposition on the grids. The disruption process resulted in Itaipu-1 and Itaipu-3 magnetosomes mixed together on the TEM grid (Figure 1). High-resolution TEM and selected area electron diffraction (SAED) measurements were made with a Philips CM200 field emission gun (FEG) TEM.

Off-axis electron holography was performed with a Philips CM200 FEG TEM operated at 200 $\mathrm{kV}$. This microscope has a rotatable electrostatic biprism (a 0.6-micron quartz wire coated with gold) located in place of one of the conventional selected-area apertures. It also has a Lorentz minilens, which is located in the bore of the objective lens pole-piece. With the conventional microscope objective lens switched off, the Lorentz minilens allows the examination of the magnetosomes in close to field-free conditions with a line resolution of $1.2 \mathrm{~nm}$ at $200 \mathrm{kV}$.

\section{PRINCIPLES OF ELECTRON HOLOGRAPHY}

In off-axis electron holography, the sample is positioned in the transmission electron microscope so that it covers approximately half the field of view, and a charged electrostatic biprism causes the electron wave that has passed through the specimen to overlap with a reference wave that has only passed through vacuum. The resulting hologram is an interference pattern in which amplitude information is contained in the relative amplitude of the cosinelike fringes, and information about the phase shift of the electron wave is contained in their position (Dunin-Borkowski et al. 1998a, b, 2001).

By recording digital holograms with a slowscan CCD camera, accurate quantification of the phase and amplitude becomes possible (de Ruijter and Weiss 1993). The complex image may be reconstructed rapidly and accurately with computer techniques by selecting a sideband associated with the cosine periodicity from the Fourier transform of the hologram and then performing the inverse Fourier transform of the sideband. Using this imaging method, both the phase and amplitude of the electron wavefront can be extracted, unlike a con- 


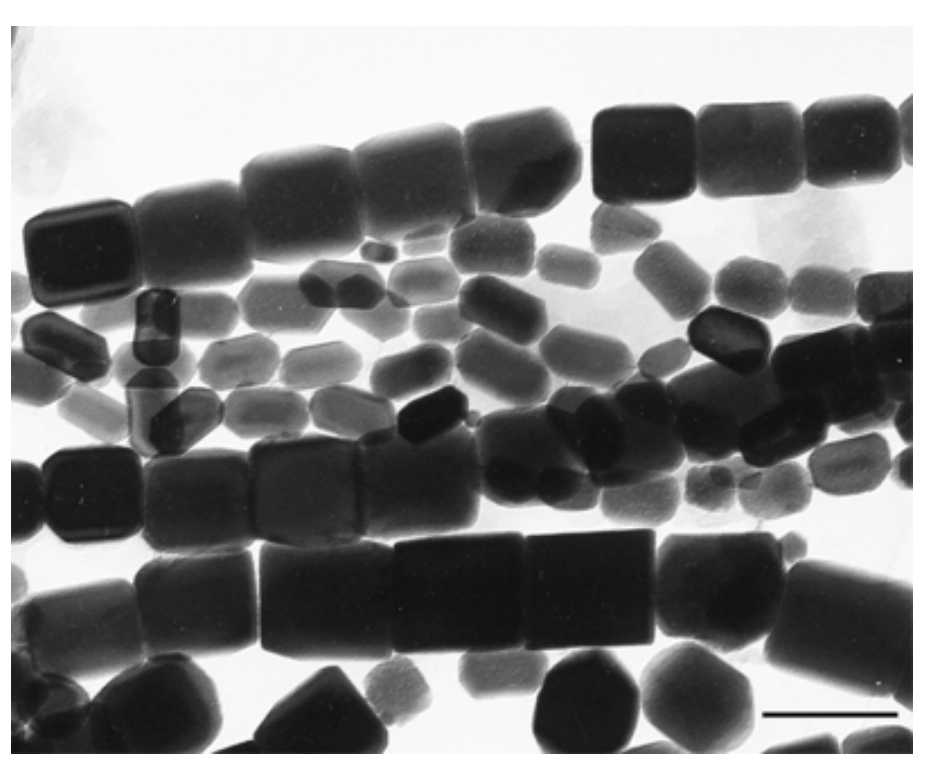

Fig. 1 - Transmission electron microscopy image of isolated chains of magnetosomes from Itaipu-1 (large crystals) and Itaipu-3 (small crystals). Scale bar indicates $200 \mathrm{~nm}$.

ventional TEM image, which represents only the intensity of the electron wave and does not contain any phase information.

For a sample with electrostatic potential, V, and magnetic vector field, $\mathrm{B}$, the phase shift, $\Delta \phi$, of the electron wave can be expressed as (Reimer 1989)

$$
\Delta \phi(\mathrm{x}, \mathrm{y})=\frac{2 \pi}{\lambda \mathrm{E}} \frac{\mathrm{E}+\mathrm{E}_{\circ}}{\mathrm{E}+2 \mathrm{E}_{\circ}} \int \mathrm{V}(\mathbf{r}) \mathrm{dz}-\frac{\mathrm{e}}{\hbar} \int \mathbf{B}(\mathbf{r}) \bullet \mathrm{d} \mathbf{S}
$$

where $\lambda, E, E_{\circ}, e, \hbar$, and $V$ are the electron wavelength, kinetic energy, rest mass energy, charge, Planck's constant, and electrostatic mean inner potential, respectively. In the absence of induced electric fields, the first integral is equal to the mean inner potential (Gajdardziska-Josifovska et al. 1993) times the sample thickness. The second integral picks out the components of the magnetic field perpendicular to the incident-beam direction, i.e., those that normally correspond to the components in the plane of the sample.

The mean inner potential is a quantity that is related to the electron-optical index of refraction and is characteristic for a particular material composition and density. In the absence of magnetic fields, it represents a constant that correlates the phase shift with the projected thickness. Normally, this quantity is determined by analyzing samples whose thickness is precisely known. Conversely, once determined, it can be used to measure the local thickness.

Two holograms corresponding to reversed orientations of the magnetization are acquired in order to analyze both the 3D shape and magnetic flux of small magnetic crystals. Reversals of the magnetization are obtained in situ by the application of the magnetic field of the objective lens (DuninBorkowski et al. 1998a, 2001). The sum of the phases of these two holograms then represents twice the mean inner-potential contribution to the phase if the magnetization has exactly reversed, whereas the difference of the phases gives twice the magnetic contribution.

Knowledge of the value of the mean inner potential for magnetite enables the electrostatic contribution to the phase to be converted directly into thickness (Gajdardziska-Josifovska et al. 1993). A preliminary estimate for the mean inner potential, $14 \mathrm{~V}$, has been made. Electron holography can thus 
provide quantitative information about the projected thicknesses of the crystallites, and holograms can be acquired for specific tilts of the crystals to provide 3D morphologies.

\section{RESULTS}

It is not possible to tell from the $2 \mathrm{D}$ images alone whether any set of lattice fringes is parallel to terminating facets or wedge-edges. Whereas the darker contrast in the centers of the crystals may indicate that the crystals are thicker there, the contrast of TEM images is an unreliable indicator of thickness and thus cannot be used to determine morphology (Buseck et al. 2001). Therefore off-axis electron holography was used to measure the cross-sectional thickness of the crystals (Lins et al. 2005) resulting in the idealized crystal habit shown in Figure 2 for Itaipu-1 crystals. Figure 3a shows the thickness contours derived from electron holograms for three Itaipu-1 crystals (labeled 1, 2 and 3) and two Itaipu-3 crystals (labeled 4, and 5). The thickness profiles across crystals 2 and 4 are shown in Figure $3 \mathrm{~b}$ whereas the thickness profiles across crystals 3 and 5 are shown in Figure 3c. The profiles of crystal 2 and 4 are consistent with a hexagonal cross-section with the electron beam in a $[2 \overline{1} \overline{1}]$ projection, corresponding to the intersection of two adjacent $\{1 \overline{1} 0\}$ planes (Figure 2). This projection has a peak (tenttop) in the center. On the other hand, the profiles of crystals 3 and 5 are consistent with hexagonal crosssections in a [110] projection, corresponding to the electron beam perpendicular to one $\{1 \overline{1} 0\}$ face and angled with respect to the adjacent two faces (Figure 2). This projection has a flat region (flat-top) in the center. We previously reported that magnetic contours for Itaipu-3 crystals were always consistent with permanent single magnetic domain structure. However, Itaipu-1 crystals presented magnetic contours consistent with permanent single magnetic domain only when crystals were arranged in linear chains (as in Figure 3a). When the chain breaks (because of the use of ultrasound during sample preparation) the magnetic contour lines did not show a single direction for the magnetization within the crystals. From these results (McCartney et al. 2001) it was concluded that large Itaipu- 1 crystals present a metastable single-domain structure.

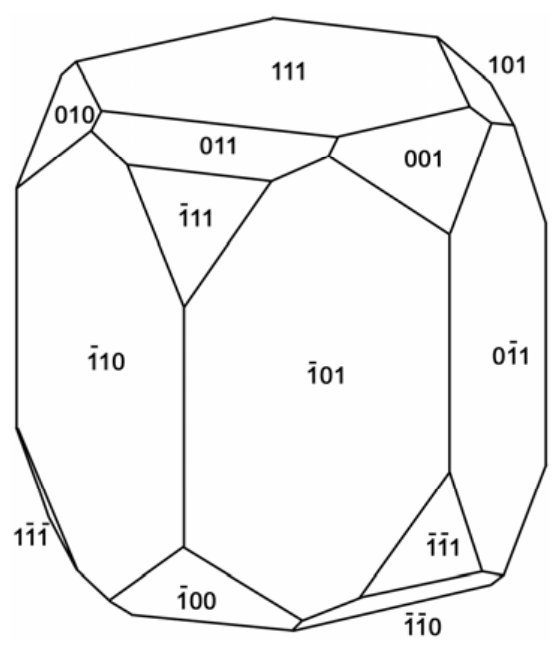

Fig. 2 - Idealized structure for elongated magnetosomes. Itaipu1 and Itaipu-3 crystals show similar morphology except for crystal length, width to length ratio, and relative development of the corner faces.

A high-resolution image of part of a crystal

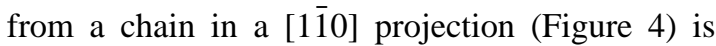
consistent with the idealized structure described for Itaipu- 1 crystals (Lins et al. 2005). It has a $\{111\}$ face at the left end of the crystal and intersections between adjacent [1 $1 \overline{10}$ ] planes at the top and bottom edges. Well-developed $\{110\}$ and $\{100\}$ corner faces occur, but possible $\{111\}$ corner faces are inconspicuous. Thus the idealized structure of the Itaipu-3 crystals is similar to that of the Itaipu- 1 crystals (Figure 2), except for length, width to length ratio, and relative development of the corner faces.

Figure 5 shows (A) thickness contours and (B) magnetic field lines for the four crystals at the left end of a chain obtained from the deviations of electron holographic fringes, as described above. The thickness profiles along the lines indicated by the arrows crossing the thickness contours are shown in (c) and (d) where half-thickness is plotted with distance along the arrows. The crystal on the left 

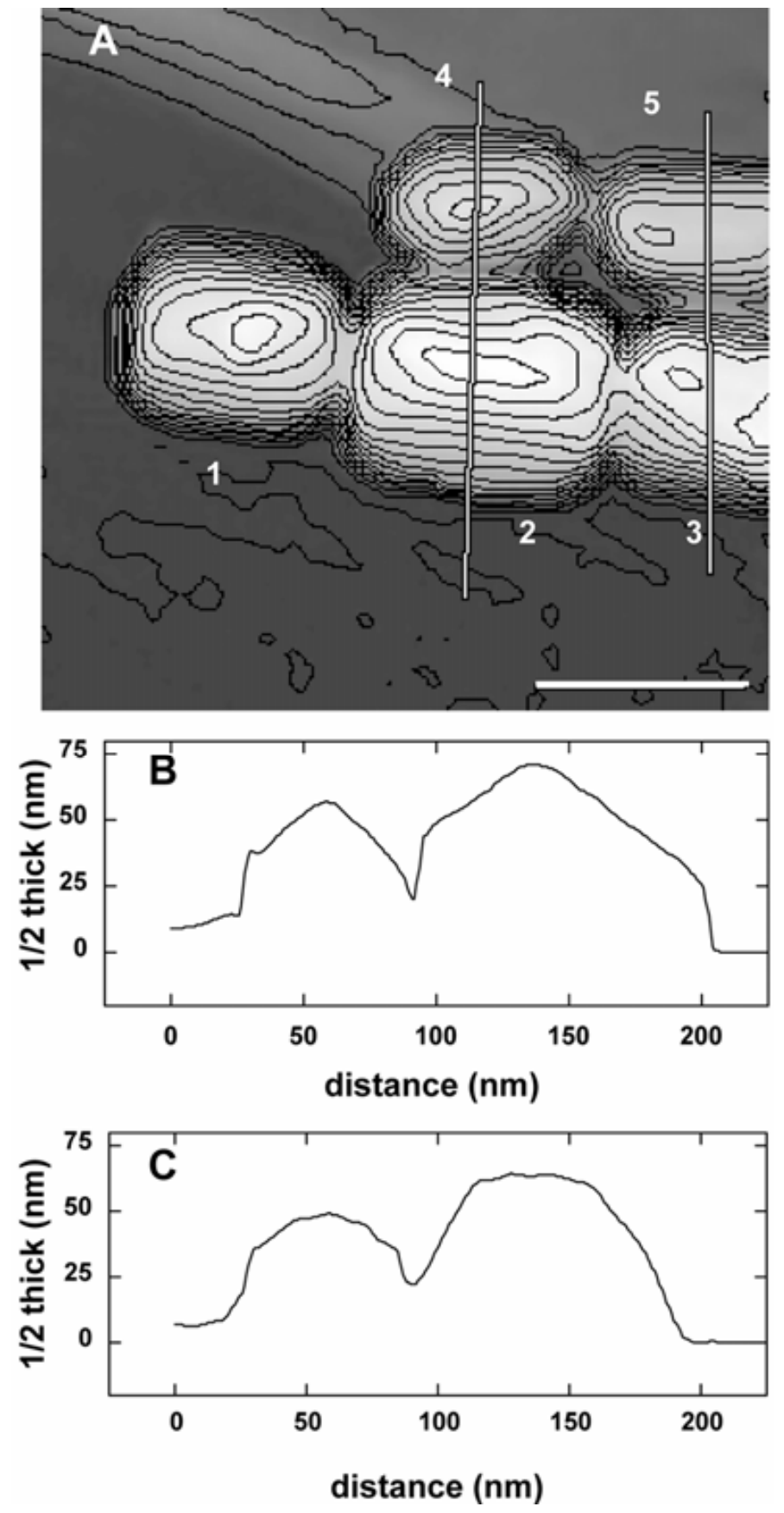

Fig. 3 - a) Cluster of three Itaipu-1 magnetosomes (crystals 1, 2 and 3) and two Itaipu-3 magnetosomes (crystals 4 and 5) with thickness contours derived from electron holographic image. (b, c) Thickness profiles for the traverses indicated by the lines. Crystal 1 is in a [110] projection zone and has a flattop profile. Crystals 2 and 4 are close to a [2실 projection zone and have a tent-top profile. Crystals 3 and 5 are in a [1 $1 \overline{0} 0$ projection zone and have a flattop profile. Scale bar indicates $150 \mathrm{~nm}$. 


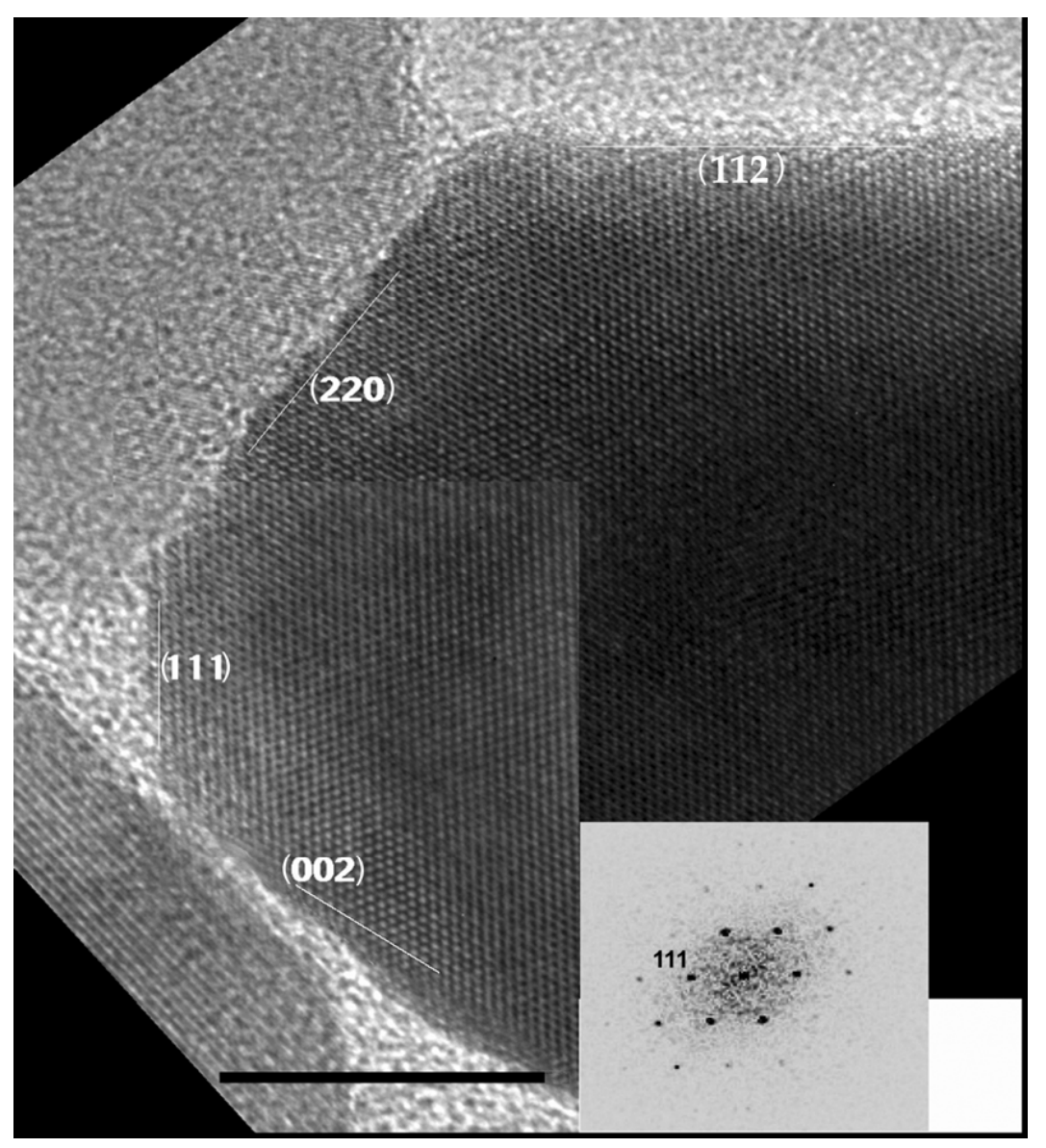

Fig. 4 - High-resolution transmission electron microscopy lattice-fringe image of an Itaipu-3 magnetosome. Inset is a diffractogram of the crystal. Scale bar indicates $15 \mathrm{~nm}$.

has a flat-top profile indicative of a [110] projection, whereas the crystal on the right has a tent-top profile indicative of a [ $2 \overline{1} \overline{1}]$ projection. These results show that both the Itaipu- 1 and Itaipu- 3 crystals have idealized habits in which [111] is a three-fold rotational axis and [1 $\overline{1} 0]$ and $[2 \overline{1} \overline{1}]$ are two-fold rotation axes. However, the surfaces of the Itaipu-3 crystals can be substantially roughened, as shown in Figure 6. This crystal also shows a [111] twin plane through its center.

\section{DISCUSSION}

We used electron holography and high-resolution TEM to determine both the 3D morphology of bac- terial magnetite crystals and their magnetic microstructure. The results confirm that both Itaipu-1 and Itaipu-3 bacteria have magnetosome magnetite crystals with similar non-equidimensional crystal habits, although the sizes of the crystals and their width to length ratios differ. In addition, the results confirm that the crystals are organized with [111] axes of elongation parallel to each other along the chain direction.

In general, magnetotactic cocci, including Itaipu-3, make larger volume magnetosomes and presumably have higher magnetic dipole moments per cell than magnetotactic spirilla or vibros (Devouard et al. 1998, Meldrum et al. 1993a, b). The cocci are also the fastest swimmers, with forward speeds 

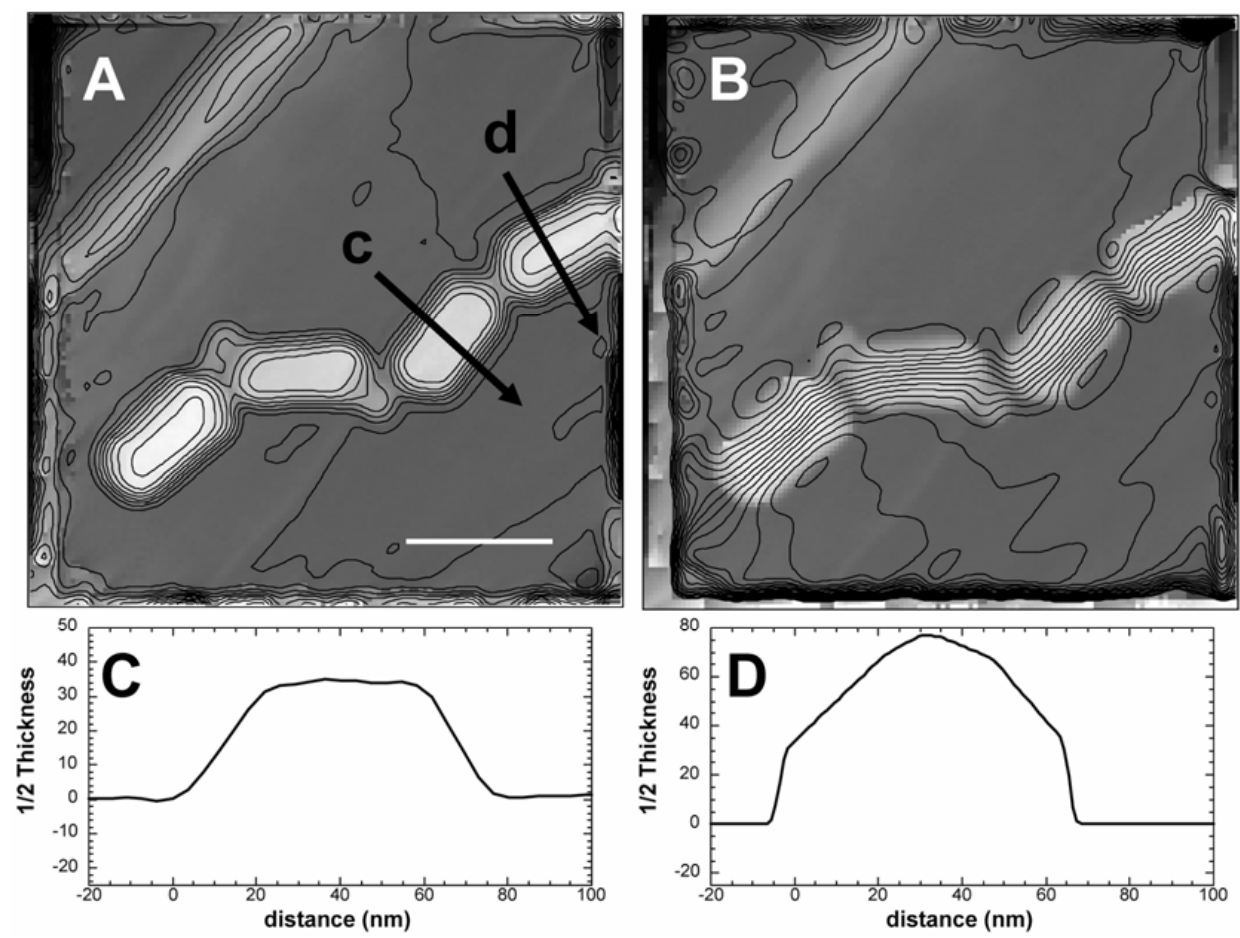

Fig. 5 - Electrostatic (A) and magnetic (B) contributions to electron holographic phase of four Itaipu-3 magnetosomes in a chain. Scale bar indicates $100 \mathrm{~nm}$ in both figures. The thickness profiles along the lines indicated by the arrows crossing the thickness contours are shown in (C) and (D) where half-thickness is plotted with distance along the arrows.

approaching 1000 microns per second (Cox et al. 2002), which requires greater propulsive forces compared to the other magnetotactic bacteria. These greater propulsive forces may result from the bilophotrichous flagellation of many coccoid magnetotactic bacteria (Frankel et al. 1997, Towe and Moench 1981). Many magnetotactic cocci are observed to make rocking motions as they swim. This would occur if the magnetic dipole in each cell were not perfectly aligned along the axis of motility of the cell, and also because flagella in magnetotactic bacteria are short (similar to or smaller than one helical turn) when compared to Escherichia coli that has very long flagella, and follows straight trajectories (Nogueira and Lins de Barros 1995).

The fact that the magnetocrystalline anisotropy of magnetite above the Verwey transition is relatively low (Moskowitz 1995) prompts the ques- tion of whether there is functional significance to the adoption by the Itaipu cocci and most, if not all, coccoid, magnetotactic bacteria, of non-equidimensional crystal habits. Because [111] axes are the "easy" magnetic axes above the Verwey transition, alignment of the [111] axes of elongation of the crystals with the axis of the magnetosome chain tends to increase the magnetocrystalline and shape anisotropy of the chain as a whole. The fact that the magnetic field lines follow the crystal elongation in Figure 5b suggests that the total anisotropy of the individual crystals is more important than the shape anisotropy of the whole chain in determining the magnetic microstructure. However, relatively straight chains are the rule and here the local crystal magnetic anisotropy adds to the overall shape anisotropy of the chain. The relatively low magnetocrystalline anisotropy of magnetite above 


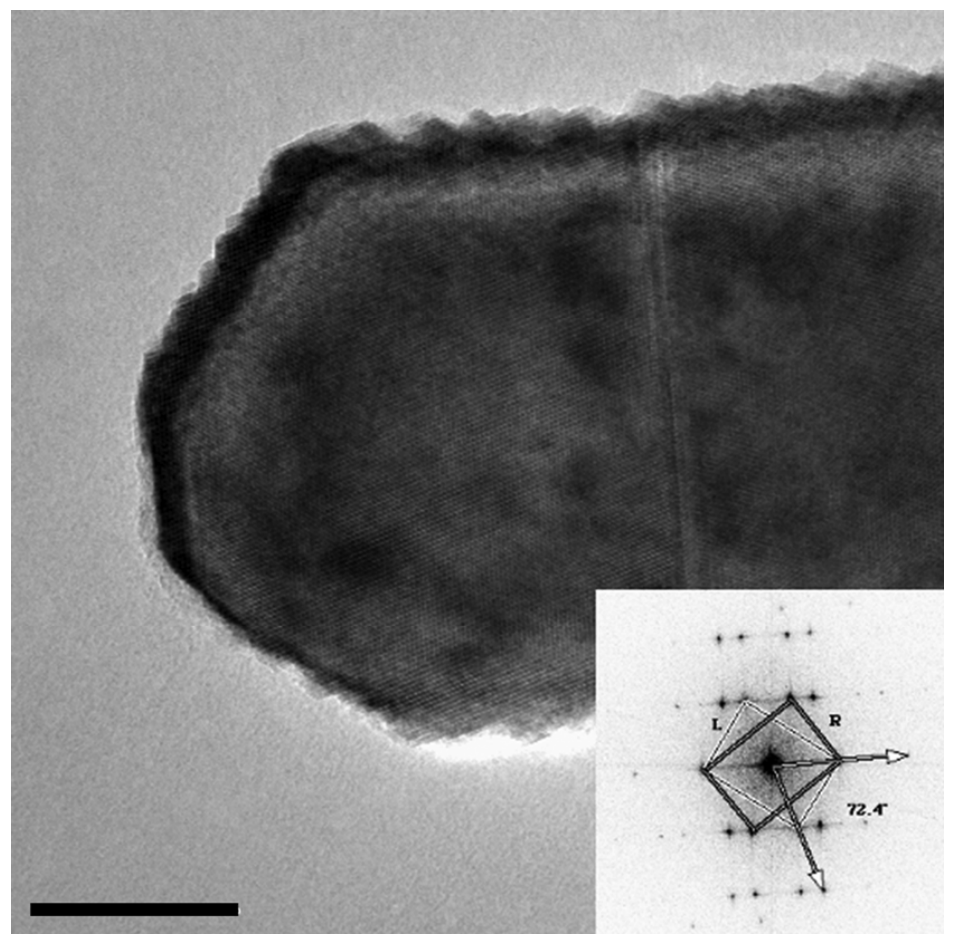

Fig. 6-High-resolution transmission electron microscopy lattice-fringe image of a twinned Itaipu-3 magnetosome showing a rough surface. Inset is a diffractogram of the crystals. Scale bar indicates $20 \mathrm{~nm}$.

the Verwey transition (Moskowitz 1995) and the slight elongation of the magnetosome crystals in Itaipu-1 suggests that the shape anisotropy of the chain alone is sufficient to keep the magnetization along the chain direction without spontaneous reversals. This may explain the presence of large $\{111\}$ contact faces between crystals, preventing misalignment of the crystals in the chain.

Although increased magnetic anisotropy probably increases the coercive force of the chain, it is not immediately apparent what, if any, effect this has on magnetotaxis. Some bacteria, such as the magnetotactic spirilla, have equidimensional magnetite crystals and yet form magnetosome chains in which the magnetic flux is well confined to the magnetite crystals in the chain. These bacteria have magnetic dipole moments per unit length that are comparable to those in bacteria with magnetosome chains containing elongated crystals (Dunin-Borkowski et al. 1998b). Also, some bacteria have magnetosome magnetite crystals with an [211] axis of elongation parallel to the chain direction (Mann et al. 1987). Although the magnetic dipole moment per unit length for chains with these crystals has not been measured, it must be of sufficient magnitude to account for the magnetotactic response of the cells. Thus elongation of magnetosomes along [111] cannot be explained by simply invoking natural selection (Thomas-Keprta et al. 2001).

An explanation for non-equidimensional habits presumably lies in the biomineralization process itself. Magnetite crystals grown in an isotropic solution free of external stresses adopt equidimensional habits with low index faces, but anions or organic molecules in the solution can influence the relative growth of those faces. In magnetotactic bacteria, the magnetite crystals form within magnetosome membranes that are thought to influence the nucle- 
ation and growth of the crystal from a saturated iron solution at the right electrochemical potential and pH such that magnetite is the stable phase (Baeuerlein 2000, Mann and Frankel 1989, Schüler 1999). Non-equidimensional growth could result from the presence of the nucleating surface or an anisotopic iron ion flux through the membrane that results in crystal habits with lowered symmetry compared to crystals grown in isotropic situations. This might also explain the occurrence of magnetosomes with arrowhead, tooth-shaped or bullet projections, i.e., with even lower symmetry than the magnetosomes in the Itaipu cocci (Blakemore et al. 1981). It would be interesting to have these cocci in pure culture to evaluate the effects of varying concentrations of oxygen, iron, and specific iron chelators on magnetosome growth.

\section{ACKNOWLEDGMENTS}

R.B.F. and P.R.B. acknowledge support from U.S. National Science Foundation grant CHE 9714101. M.F. acknowledges support from Conselho Nacional de Desenvolvimento Científico e Tecnológico $(\mathrm{CNPq})$ and U.L. acknowledges support from $\mathrm{CNPq}$, Coordenação de Aperfeiçoamento de Pessoal de Nível Superior (CAPES), Fundação Carlos Chagas Filho de Amparo à Pesquisa do Estado do Rio de Janeiro (FAPERJ), Programa de Apoio a Núcleos de Excelência (PRONEX). Electron microscopy was performed at the Center for High Resolution Electron Microscopy at Arizona State University. U.L. thanks P.R.B. for the opportunity to spend time at Arizona State University to work on the manuscript.

\section{RESUMO}

Nós relatamos a aplicação de holografia não-axial e microscopia eletrônica de alta resolução para estudar os hábitos cristalinos de magnetossomos e a microestrutura magnética de dois morfotipos de cocos de bactérias magnetotáticas coletadas em uma lagoa salobra em Itaipu, Brasil. Itaipu-1, o organismo cocóide maior, contém duas cadeias separadas de magnetossomos atipicamente grandes; os cristais dos magnetossomos possuem projeções aproximadamente quadradas, comprimentos de até $250 \mathrm{~nm}$ e são ligeiramente alongados na direção [111] (razão largura/comprimento de aproximadamente 0.9). Os cristais dos magnetossomos em Itaipu-3 possuem comprimentos até $120 \mathrm{~nm}$, maior alongamento na direção [111] (largura/comprimento $\sim 0.6$ ), e proeminentes facetas nas extremidades. Os resultados mostram que os hábitos cristalinos dos magnetossomos em Itaipu-1 e Itaipu-3 são relacionados, diferindo apenas nos tamanhos relativos das suas faces cristalinas. Em ambos os casos, os cristais são alinhados com seus eixos de alongamento [111] paralelos à direção da cadeia. Em Itaipu1, mas não em Itaipu-3, o posicionamento cristalográfico, perpendicular à direção [111], de cristais sucessivos na cadeia de magnetossomos parece estar sobre controle biológico. Enquanto os magnetossomos grandes em Itaipu-1 são monodomínios magnéticos metaestáveis, em Itaipu-3 eles são monodomínios magnéticos permanentes como na maioria das bactérias.

Palavras-chave: magnetita, magnetotaxia, microscopia eletrônica de transmissão de alta resolução.

\section{REFERENCES}

BAeUerlein E. 2000. Single magnetic crystals of magnetite $\left(\mathrm{Fe}_{3} \mathrm{O}_{4}\right)$ synthesized in intracytoplasmic vesicles of Magnetospirillum grysphiswaldense. In: BAEUERLEIN E (Ed), Biomineralization: From biology to biotechnology and medical application, Weinheim, Germany: Wiley-VCH, p. 61-79.

BAZYLINSKI DA AND FRANKEL RB. 2000. Magnetic iron-oxide and iron-sulfide minerals within microorganisms. In: BAEUERLEIN E (Ed), Biomineralization: from biology to biotechnology and medical application, Weinheim, Germany: Wiley-VCH, p. $25-46$.

BAZYLINSKi DA AND FRANKEL RB. 2004. Magnetosome formation in prokaryotes. Nature Rev Microbiol 2: 217-230.

BAZYLinski DA, Garratt-ReEd AJ AND Frankel RB. 1994. Electron microscopic studies of magnetosomes in magnetotactic bacteria. Microsc Res Tech 27: $389-401$.

BLAKEMORE RP, FRANKel RB AND KALMiJn AJ. 
1981. South-seeking magnetotactic bacteria in the Southern Hemisphere. Nature 286: 384-385.

Buseck PR, DUNIN-BORKOWSKI RE, DEVOUARD B, Frankel RB, McCartney MC, Midgley PA, Posfai M and Weyland M. 2001. Magnetite morphology and life on Mars. Proceed Nat Acad Sci USA 98: 13490-13495.

Cox BL, Popa R, BAzYlinski D, LANoil B, Douglas S, Belz A, Engler DL and Nealson KH. 2002. Organization and elemental analysis of $\mathrm{P}-, \mathrm{S}-$, and Fe-rich inclusions in a population of freshwater magnetococci. Geomicrobiol J 19: 387406.

DE RUiJTer WJ AND Weiss JK. 1993. Detection limits for quantitative off-axis electron holography. Ultramicroscopy 50: 269-283.

Devouard B, Posfai M, Hua X, Bazylinski DA, Frankel RB AND Buseck PR. 1998. Magnetite from magnetotactic bacteria: Size distributions and twinning. Amer Mineral 83: 1387-1399.

Dunin-Borkowski RE, MCCARTNEY MR, SMITH DJ AND PARKIN SSP. 1998a. Towards quantitative electron holography of magnetic thin films using in situ magnetization reversal. Ultramicroscopy 74 : 61-73.

Dunin-Borkowski RE, MCCARTNEY MR, FRANKEL RB, BAZYLINSKI DA, PÓSFAi M AND BUSECK PR. 1998b. Magnetic microstructure of magnetotactic bacteria by electron holography. Science 282: $1868-1870$.

Dunin-Borkowski RE, MCCARTNEy MR, PósFai M, FRANKEL RB, BAZYLINSKI DA AND BUSECK PR. 2001. Off-axis electron holography of magnetotactic bacteria: magnetic microstructure of strains MV-1 and MS-1. Eur J Mineral 13: 671-684.

FARINA M, KACHAR B, LiNS U, BRODERICK R AND LINS DE BARROS H. 1994. The observation of large magnetite $\left(\mathrm{Fe}_{3} \mathrm{O}_{4}\right)$ crystals from magnetotactic bacteria by electron and atomic force microscopy. $\mathrm{J} \mathrm{Mi-}$ crosc 173: 1-8.

FrANKEL RB AND BUSECK PR. 2000. Magnetite biomineralization and ancient life on Mars. Curr Opin Chem Biol 4: 171-176.

FRANKEL RB, BAZYLINSKI DA, JOHNSON MS AND TAYLOR BL. 1997. Magneto-aerotaxis in marine coccoid bacteria. Biophys J 73: 994-1000.
GAJDARDZISKA-JOSIFOVSKA M, MCCARTNEY MC, DE RUiJTer WJ, SMith DJ, Weiss JK AND Zuo JM. 1993. Accurate measurement of mean inner potential of crystal wedges using digital electron holograms. Ultramicroscopy 50: 285-299.

Lins U AND FARINA M. 1998. Magnetosome size distribution in uncultured rod-shaped bacteria as determined by electron microscopy and electron spectroscopic imaging. Microsc Res Tech 42: 459-464.

Lins U, SOlÓRZANO G AND FARINA M. 1994. High volume magnetite $\left(\mathrm{Fe}_{3} \mathrm{O}_{4}\right)$ crystals from magnetotactic bacteria. Bull Inst Oceanogr Monaco 14: 95104.

Lins U, Freitas F, KeIM CN, Lins de Barros H, ESQuivel DMS AND FARINA M. 2003 Simple homemade apparatus for harvesting uncultured magnetotactic microorganisms. Braz J Microbiol 34: 111-116.

LINS U, MCCARTNEY MR, FARINA M, FRANKEL RB AND BUSECK PR. 2005. Habits of magnetosome crystals in coccoid magnetotactic bacteria. Appl Environ Microbiol 71: 4902-4905.

MANN S AND FrANKEL RB. 1989. Magnetite biomineralization in unicellular organisms. In: MANN S ET AL. (Eds), Biomineralization: Chemical and Biochemical perspectives. Weinheim, Germany: WileyVCH, p. 389-426.

ManN S, Frankel RB AND Blakemore RP. 1984. Structure, morphology and crystal-growth of bacterial magnetite. Nature 310: 405-407.

ManN S, Sparks N AND Blakemore RP. 1987. Structure, morphology and crystal growth of anisotropic magnetite crystals in magnetotactic bacteria. Proc R Soc London Ser B 231: 477-487.

Matsuda T, Endo J, Osakabe N, Tonomura A AND ARII T. 1983. Morphology and structure of biogenic magnetite particles. Nature 302: 411-412.

Matsunaga T And OKamura Y. 2003. Genes and proteins involved in bacterial magnetic particle formation. Trends Microbiol 11: 536-541.

McCartney MR, Lins U, Farina M, Buseck PR AND FRANKEL RB. 2001. Magnetic microstructure of bacterial magnetite by electron holography. Eur J Mineral 13: 685-689.

Meldrum FC, Mann S, Heywood BA, Frankel RB AND BAZYLINSKI DA. 1993a. Electron micro- 
scope study of magnetosomes in a cultured coccoid magnetotactic bacterium. Proc R Soc London Ser B 251: 231-236.

Meldrum FC, Mann S, Heywood BA, Frankel RB AND BAZYLINSKI DA. 1993b. Electron microscope study of magnetosomes in two cultured vibrioid magnetotactic bacteria. Proc R Soc London Ser B 251: 237-242.

Moskowitz BM. 1995. Biomineralization of magnetic minerals. Rev Geophys 33: 123-128.

NogueIRA FS AND Lins de BARRos HGP. 1995. Study of the motion of magnetotactic bacteria. Eur Biophys J 24: 13-22.

REIMER L. 1989. Transmission electron microscopy. Physics of image formation and microanalysis. Springer Series in Optical Sciences $2^{\text {nd }}$ ed., Berlin: Springer 36: 584.

SCHÜLER D. 1999. Formation of magnetosomes in magnetotactic bacteria. J Mol Microbiol Biotechnol 1: 79-86.

SCHÜLER D. 2004. Molecular analysis of a subcellular compartment: the magnetosome membrane in Magnetospirillum gryphiswaldense. Arch Microbiol 18: 1-7.
Simmons SL, Sievert SM, Frankel RB, BAZYLINSKI DA AND EDWARDS KJ. 2004. Spatiotemporal distribution of marine magnetotactic bacteria in a seasonally stratified coastal salt pond. Appl Environ Microbiol 70: 6230-6239.

Spring S, Lins U, Amann R, Schleifer K, FerREIRA LCS, ESQUIVEL DMS AND FARINA M. 1998. Phylogenetic affiliation and ultrastructure of uncultured magnetic bacteria with unusually large magnetosomes. Arch Microbiol 169: 136-147.

Thomas-Keprta TL, Bazylinski DA, Clemett SJ, KirschVink JL, MCKAY DS, Wentworth SJ, VAli H, Gibson-JR EK, McKay MF AND ROMANEK CS. 2001. Truncated hexa-octahedral magnetite crystals in ALH84001: presumptive biosignatures. Proc Natl Acad Sci USA 98: 2164-2169.

Towe KM AND MoENCH TT. 1981. Electron-optical characterization of bacterial magnetite. Earth Planet Sci Lett 52: 213-220. 